\title{
Comparison of shear bond strength of orthodontics brackets on composite resin restorations with different surface treatments
}

\author{
Alexandre Antonio Ribeiro, Ariane Vicente de Morais², Daniel Paludo Brunetto³, \\ Antonio Carlos de Oliveira Ruellas ${ }^{4}$, Monica Tirre Souza de Araujo ${ }^{5}$
}

Introduction: Orthodontic patients frequently present composite resin restorations, however there are few studies that evaluate the best way for orthodontic bonding in this situation. Objective: The objective of this work was to evaluate the bond strength of orthodontic brackets in resin restorations with surface treatment. Methods: Fifty one bovine lower incisors were randomly divided into three groups. On the control group (CG) the brackets were bonded to dental enamel; on experimental groups, brackets were bonded to resin restoration with diamond drill treatment (EGT) and with no treatment (EGN). The teeth were placed in PVC tubes with autopolymerized acrylic resin. The shear test was performed in EMIC universal testing machine. The groups were submitted to ANOVA analysis of variance with Tukey post test to verify the statistical difference between groups $(\alpha=0.05)$. Results: CG $(6.62 \mathrm{MPa})$ and EGT $(6.82 \mathrm{MPa})$ groups presented similar results, while EGN (5.07 MPa) obtained statistically lower results $(\mathrm{p}<0.05)$. Conclusion: Therefore, it is concluded that the best technique for bonding of orthodontic brackets on composite resin restorations is the performance of surface detritions.

Keywords: Shear bond strength. Dental restoration. Dental bonding

Introdução: frequentemente, os pacientes ortodônticos apresentam restaurações de resina composta; no entanto, existem poucos estudos que avaliam a melhor forma de colagem ortodôntica nessa situação. Objetivo: o objetivo do presente trabalho foi avaliar a força adesiva de braquetes ortodônticos em restaurações resinosas com tratamento de superfície. Métodos: foram utilizados 51 incisivos inferiores bovinos divididos aleatoriamente em três grupos. No grupo controle (GC), os braquetes foram colados em esmalte dentário; nos grupos experimentais com tratamento (GCT) e sem tratamento (GST), os braquetes foram colados em restauração de resina previamente realizada, diferenciando-se pelo tratamento de superfície com broca diamantada. Os dentes foram incluídos em tubos de PVC com resina acrílica autopolimerizável. O ensaio de cisalhamento foi executado em máquina universal de ensaios Emic. Os grupos foram submetidos à ANOVA com pós-teste de Tukey para verificação da diferença estatística entre os grupos $(\alpha=0,05)$. Resultados: GC (6,62MPa) e GCT (6,82MPa) apresentaram resultados semelhantes, enquanto o GST (5,07MPa) obteve resultados estatisticamente menores $(\mathrm{p}<0,05)$. Conclusão: conclui-se que a melhor técnica de colagem de braquetes ortodônticos em restaurações de resina composta é a de realização de desgaste sobre a superfície.

Palavras-chave: Resistência ao cisalhamento. Desgaste de restauração dentária. Colagem dentária.

${ }^{1} \mathrm{PhD}$ Student in Dental Sciences, UNESP/Araraquara.

${ }^{2}$ Graduate d in Dentistry, Federal University of Rio de Janeiro - UFRJ.

${ }^{3} \mathrm{MSc}$ in Dentistry, UFRJ.

${ }^{4} \mathrm{PhD}$ in Orthodontics, UFRJ. Post-doc in Material and Metallurgical

Engineering, UFRJ.

${ }^{5} \mathrm{PhD}$ in Orthodontics, UFRJ. Assistant Professor, UFRJ.

" The authors report no commercial, proprietary or financial interest in the products or companies described in this article.
How to cite this article: Ribeiro AA, Morais AV, Brunetto DP, Ruellas ACO, Araujo MTS. Comparison of shear bond strength of orthodontics brackets on composite resin restorations with different surface treatments. Dental Press J Orthod. 2013 July-Aug;18(4):98-103.

Submitted: April 11, 2011 - Revised and accepted: June 13, 2011

Contact address: Alexandre Antonio Ribeiro Av. Antônio Basílio, 3660 - Apto 701 - Lagoa Nova - Natal/RN, Brazil CEP: 59054380 - E-mail: alexandrear23@hotmail.com 


\section{INTRODUCTION}

The direct bonding of brackets became a conventional protocol after innumerable studies that proved its effectiveness, especially regarding the debonding (shear). ${ }^{1-6}$ According to literature, appliances bonded to the enamel must have shear bond strength between 6 and $8 \mathrm{MPa}^{2,5,7}$ in order to achieve the clinical needs that support orthodontic and occlusion forces. ${ }^{8}$ On the other hand, they must not present exceeding bond strength that may cause enamel cracks or fractures during debonding of appliances. Other authors mentioned variations of $20 \mathrm{MPa}$ as highest acceptable bond strength. ${ }^{9,10}$

Today, it is observed considerable increase of adults seeking orthodontic treatment, due to greater number of professional orthodontists, great valorization of esthetics, access to affordable dental materials and awareness of the necessity of orthodontic therapy. It is quite common to find in this group of patients, or even in younger patients, restorations of amalgam, composite resins or ceramics. Authors assert that recent progress on materials and techniques indicate that it is possible an effective direct bonding of orthodontic appliances on the surface of these materials. ${ }^{11,12}$

In relation to the amalgam surface, studies show that the bond strength is inferior to the obtained on enamel, ${ }^{12,13}$ however the creation of mechanical retention with aluminium oxide blasting on the surface ${ }^{13,14}$, roughening with diamond tip or confection of wholes with spheric drill $1 / 4$ increases the bond strength of the orthodontic material to the restorative material. ${ }^{14}$ Other works ${ }^{15}$ show that for porcelain restorations the best results were observed when it was applied phosphoric acid at 37\% for 60 seconds for cleaning, followed by application of silane, adhesive system and adhesive resin. On the other hand, others affirm the necessity of hydrofluoric acid application, posteriorly using silane specific for porcelain. ${ }^{3,11,15}$

Authors ${ }^{3,12,14}$ assert that the bonding of brackets on surfaces restored with composite resin is similar to technique recommended for amalgam and porcelain, however, it were not found enough studies for such affirmation. Therefore, the objective of this work was to evaluate the bond strength on teeth with composite resin restorations under different surface treatments, as well as to correlate these results with the adhesive remnant index (ARI).

\section{MATERIAL AND METHODS}

\section{Sample}

Fifty one bovine lower incisors were stored in Timol $0.1 \%$ and refrigerated at $5{ }^{\circ} \mathrm{C}$, for assemblage of specimens. The specimens were randomly divided into three groups: Control group (CG) (brackets bonded to dental enamel) and experimental groups with and without surface treatment, EGT and EGN, respectively. Brackets were bonded to resin restoration previously performed).

\section{Assemblage of specimens}

Initially, it was performed the polishing of the dental enamel with water sandpaper of silicon carbide (granulation 1200) making the surface free of roughness. The teeth were embedded in PVC tubes with autopolymerized acrylic resin JET (Clássico Artigos Odontológicos - Campo Limpo Paulista, Brazil). The vestibular face of each tooth was positioned perpendicular to the base of the PVC tube with assistance of an acrylic set-square. After placing teeth into the tubes, samples were stored for 24 hours for the complete resin polymerization (Fig 1).

To limit the area to be restored on experimental groups, it were performed cavities of $0.5-1 \mathrm{~mm}$ deep with diamond spheric drill 3018HL (Microdont São Paulo, Brazil) on the middle third of the dental crown. The size of the groove for restoration corresponds to a larger area than the base of the bracket to be bonded $\left(16 \mathrm{~mm}^{2}\right)$. Then, the cavities were restored following orientations from the manufacturer of 4 Seasons composite resin (thin particles for restorations highly esthetical, Ivoclar Vivadent - Schaan, Liechtenstein) and using adhesive Adper Single Bond 2 (3M ESPE - St. Paul, USA). The specimens were immersed in recipient with artificial saliva for one week. Posteriorly, finishing with drill for composite resin 3195F (KG Sorensen - São Paulo, Brazil) and polishing with Enhance tips, Poligloss paste and sanding discs (TDV - Pomerode, Brazil) were performed.

For the group with treatment (EGT) superficial detrition of composite resin restoration through application in one way of the diamond milling cutter 2200 (Microdont - São Paulo, Brazil) was performed, without any type of groove, for increase of mechanical retention. The specimens were immersed again in recipient with artificial saliva at $37^{\circ} \mathrm{C}$. 


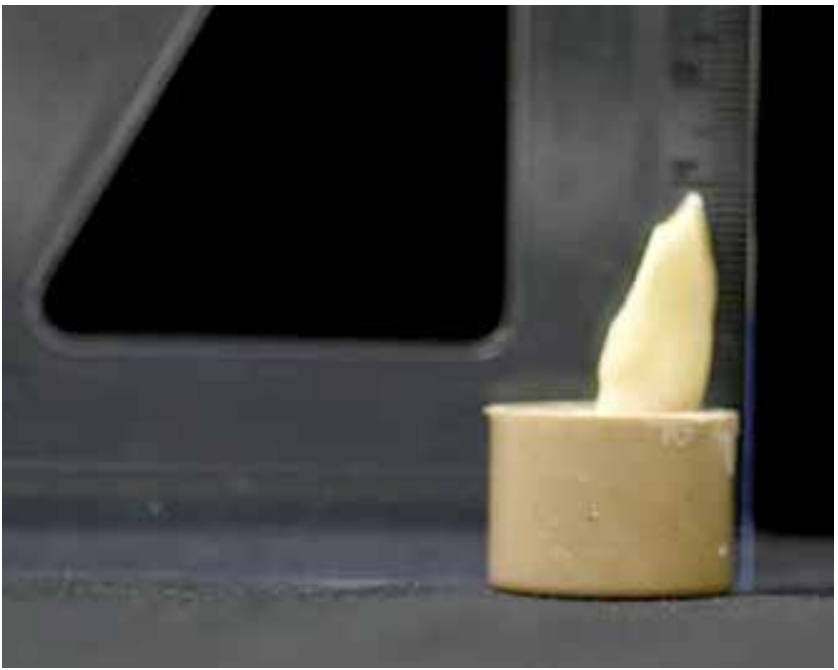

Figure 1 - Photograph of specimen showing vestibular face perpendicula to the ground.

\section{Bonding of brackets}

The specimens from the three groups were cleansed through prophylaxis with pumice and water for 10 seconds using low rotation micromotor and rubber cup. Then the specimens were rinsed and dried with air for 10 seconds. The bonding of brackets was done by standardized $200 \mathrm{gf}$ pressure with assistance of a tensiometer.

The groups received direct bonding of brackets Edgewise Standard Slim, for upper central incisors of dimensions $0.022 \times 0.030$-in (Dental Morelli, Sorocaba, Brazil). The specimens received acid conditioning (orthophosphoric) at 37\%, adhesive Transbond XT Light Cure Adhesive Primer (3M Unitek - Monrovia, USA) and resin Transbond XT (3M Unitek - Monrovia, USA), according to manufacturer's instructions.

The exceeding orthodontic resin was removed with explorer previously to the polymerization performed for 30 seconds with the device Ultraled (Dabi Atlante - Ribeirão Preto, Brazil). After the bonding of brackets, the specimens were stored in distilled water at $37^{\circ} \mathrm{C}$, during 7 days for posterior shear test.

\section{Shear test}

The shear test was performed in EMIC DL 10.000 (São José dos Pinhais, Brazil) machine with speed of $1 \mathrm{~mm} /$ minute and load cells of $10 \mathrm{kN}$. The results of maximum force were recorded by the software Mtesc, version 1.01 (EMIC). The data were obtained in Megapascal (MPa).

\section{Adhesive remnant index}

After performing the shear test, the interface enamel-resin was examined in stereoscopic microscope Carl Zeiss (Göttingen, Germany), binocular model KL 1500 LCD with attached photographic camera Pixelink, on magnification of $16 \mathrm{X}$ to determine the amount of remnant resin (Fig 2). This was classified according to Adhesive remnant index which score ranges from 0 to 3 being:

" 0 - indicative of absence of remnant composite;

" 1 - less than a half of composite remained;

" 2 - more than a half of composite remained, and

" 3 - all the composite remained adhered to the dental enamel.

\section{Statistical analysis}

The statistical analysis was performed on SPSS program version 16.0 (Statistical Package for Social Sciences; SPSS Inc., Chicago, IL, USA). Initially, it was done descriptive analysis of the groups, as well as verification of normality by Shapiro-Wilk test and intraexaminer agreement by weighted Kappa test for Adhesive remnant index.

The groups were submitted to analysis of variance (one-way ANOVA) with Tukey post test for verification of statistical difference.

Finally, it was done the Spearman correlation, given the regular distribution of groups, between ARI and the bond strength. The confidence interval was of $95 \%(p<0.05)$.

\section{RESULTS}

The descriptive analysis showed variability quite low, mean and standard deviation $6.44 \pm 1.28$; $7.01 \pm 1.61$; and $5.06 \pm 1.35 \mathrm{MPa}$ for groups $\mathrm{CG}$, EGT and EGN, respectively (Table 1). After verification of normality of groups, it was applied the analysis of variance for one criteria (Table 2), results showed statistically significant difference, and Tukey post test was applied for elucidation of which groups were different (Table 3).

Table 4 describes the groups according to adhesive remnant index and Spearman correlation coefficient for each group in study. For intraexaminer calibration, 17 specimens were used, the weighted Kappa measure of agreement presented value of $r=0.843$ with statistical significance $(\mathrm{p}<0.001)$. 

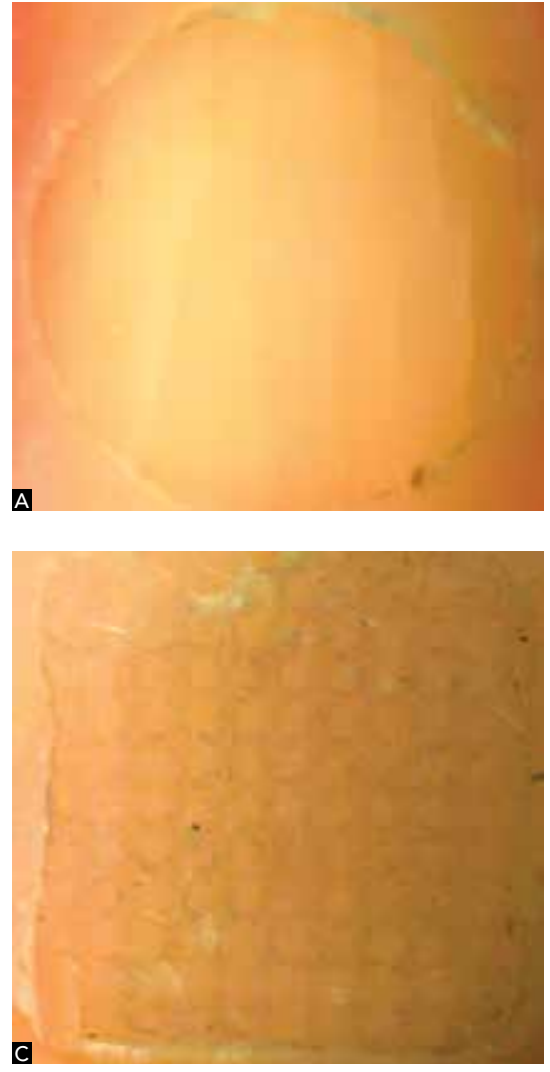
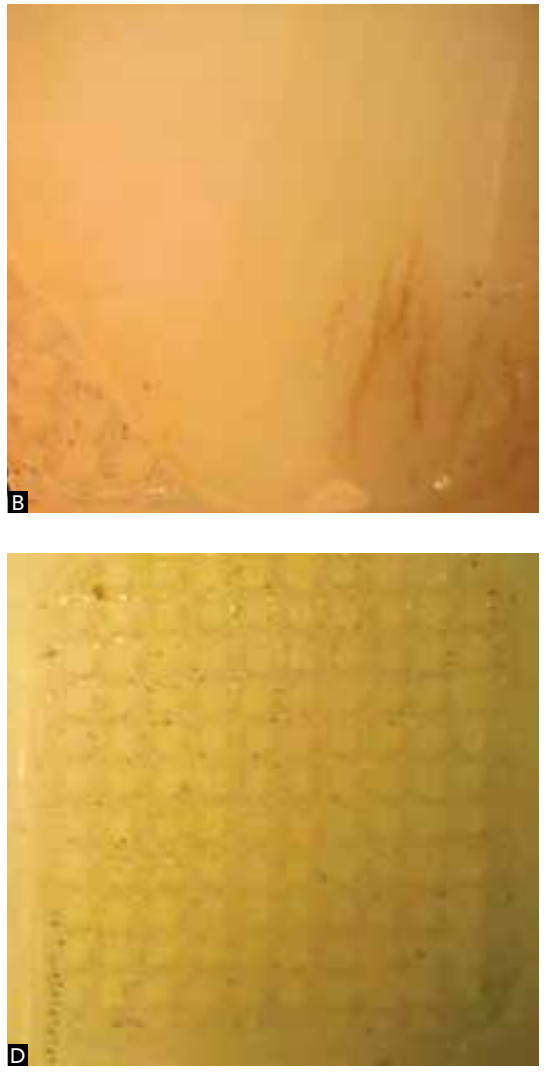

Figure 2 - ARI scores: 0 (A); 1 (B); 2 (C); 3 (D) evaluated under stereoscopic magnifying glass with magnification of $16 \mathrm{X}$.
Table 1 - Descriptive analysis of three groups according to shear strength (MPa).

\begin{tabular}{cccccccc}
\hline Group & n & $\begin{array}{c}\text { Mini- } \\
\text { mum }\end{array}$ & $\begin{array}{c}\text { Maxi- } \\
\text { mum }\end{array}$ & Mean \pm SD & $\begin{array}{c}\text { Coefficient } \\
\text { of variation }\end{array}$ & $\begin{array}{c}\text { Standard } \\
\text { error }\end{array}$ \\
CG & 17 & 3.74 & 9.18 & 6.62 & 1.28 & 19.37 & 0.31 \\
EGT & 17 & 4.56 & 9.88 & 6.82 & 1.61 & 23.69 & 0.39 \\
\hline EGN & 17 & 3.10 & 7.68 & 5.07 & 1.35 & 26.66 & 0.32 \\
\hline
\end{tabular}

Table 2 - Analysis of variance (ANOVA one-way) comparing the shear strength between the three groups.

\begin{tabular}{cccc}
\hline Number of groups & $\boldsymbol{F}$ & $\mathbf{R}^{2}$ & $\mathbf{P}$ \\
3 & 7.658 & 0.2419 & 0.0013 \\
\hline
\end{tabular}

Table 3 - Tukey post test evidencing differences between groups (2x2).

\begin{tabular}{ccccc}
\hline Group & $\begin{array}{c}\text { Mean } \\
\text { difference }\end{array}$ & Q & Significance & $\begin{array}{c}\text { Difference } \\
\text { of Cl } 95 \%\end{array}$ \\
CG vs EGT & -2.034 & 0.5762 & N.S. & -14.12 to 10.05 \\
\hline CG vs EGN & 15.81 & 4.479 & $* *$ & 3.720 to 27.89 \\
\hline EGT vs EGN & 17.84 & 5.055 & $* *$ & 5.754 to 29.93 \\
\hline
\end{tabular}

$* *=p<0.01$.

Table 4 - Values for each value of Adhesive Remnant Index (ARI) and Spearman correlation with shear bond strength of studied groups.

\begin{tabular}{|c|c|c|c|c|c|c|c|c|c|c|}
\hline \multirow{3}{*}{ Group } & \multicolumn{8}{|c|}{ ARI values } & \multirow{3}{*}{$r$} & \multirow{3}{*}{$\mathbf{p}$} \\
\hline & \multicolumn{2}{|r|}{0} & \multicolumn{2}{|r|}{1} & \multicolumn{2}{|r|}{2} & \multicolumn{2}{|r|}{3} & & \\
\hline & $\mathbf{n}$ & $\%$ & $n$ & $\%$ & $n$ & $\%$ & n & $\%$ & & \\
\hline EGN & 7 & 41.17 & 5 & 29.41 & 4 & 23.52 & 1 & 5.88 & 0.713 & 0.001 \\
\hline EGT & 0 & 0.0 & 4 & 23.52 & 6 & 35.29 & 7 & 41.17 & 0.936 & 0.000 \\
\hline$C G$ & 0 & 0.0 & 2 & 11.76 & 10 & 58.82 & 5 & 29.41 & 0.816 & 0.000 \\
\hline
\end{tabular}

\section{DISCUSSION}

This work found similar results for groups CG (6.62 $\mathrm{MPa})$ and EGT (6.82 $\mathrm{MPa}$ ) and statistically superior to EGN (5.07) (Tables 1 to 3). These values of CG and EGT are considered acceptable for clinical use. However, the values for EGN may be questionable, given that the results from this group are found out of the range of recommended bond strength (6-8 MPa) ${ }^{2,5,7}$

The orthodontic resin used in this study was Primer Transbond XT (3M Unitek, Monrovia, USA), basically composed of Triethylene glycol dimethacrylate (Bis-GMA), silica, silane, N-dimethyl benzocaine, hexafluoride phosphate. This composition is very similar to the composites used for orthodontic bonding of other manufacturers, except the composites chemically activated that presents Benzoyl peroxide as catalyst.

These components are the same present in composite resins for anterior and posterior teeth. The difference between orthodontic bonding resins and restoratives resins is the percentage of each component and the size of inorganic particles (about $8 \mu \mathrm{m}$ for orthodontic resins). The orthodontic resins present greater fluidity than restorative composites, and larger amount 
of organic matrix, while restorative resins need more esthetic and excellent mechanical properties, larger amount of inorganic load and less fluidity. ${ }^{16}$

The inappropriate bond strength for EGN can be explained by the absence of chemical interaction. In this situation, it is found a superficial layer of composite resin non reactive due the inexistence of free resinous monomer for chemical bonding. ${ }^{17}$ This situation with free and reactive monomers would occur when bonding of orthodontic brackets is done right after finishing the composite resin restoration on the tooth to be restored without contact with oral fluids. However, this situation is quite rare in orthodontic practice. Besides, it is concluded that the conditioning of resinous surface with phosphoric acid at 37\% for 30 seconds was not capable to produce any roughness on these surfaces that would allow mechanic imbrication.

Some professionals apply hydrofluoric acid, used on the bonding of brackets in ceramic surfaces, for the bonding on composite resin restorations. However, this procedure is not justified from the point of view of provision of roughness on the resin surface, because the hydrofluoric acid is specific for ceramic surfaces (vitreous), different from resinous. ${ }^{2,12}$ Actually, it would be necessary the study of another acid that is able to condition the plastic surface of resins.

Because orthodontic and restorative resins have similar compositions, the method for bonding of orthodontic appliances on teeth with previous composite resin restorations is the same as the procedure of repair of restorative resins. The repair occurs when a composite resin restoration is done over another, as in cases of partial fracture of restoration or removal of superficial layer due to unsatisfactory coloration and substitution for a more esthetic one. ${ }^{16}$

In this regard, studies about resin restoration repair ${ }^{17,18}$ prove that surface treatments with aluminium jet and superficial detrition with diamond drills present bond strength superior to surfaces with no treatment, as confirmed on the present study. These works also show through scanning electron microscopy the mechanic imbrication of these composites. ${ }^{18}$ Besides, such justification is added to the result of Spearman correlation (Table 4) for the adhesive remnant index, that showed larger amount of orthodontic resin on the resinous restorations of groups EGT and CG while for EGN, most of the orthodontic resin remained on the base of the bracket.

Clinically some patients can refuse the resin restoration detrition with diamond drill claiming the necessity of restore it at the end of the treatment. However it is valid to say that at the end of the orthodontic treatment, after the debonding of brackets, it will be necessary the removal of remnant orthodontic resin adhered to the restoration, possibly leading to unwanted detrition of this surface.

\section{CONCLUSIONS}

It is concluded that the surface treatment with diamond drills on resin restoration for bonding of orthodontic brackets provides bond strength similar to the bonding direct on the enamel. The ARI showed the lack of interaction between the resin restoration without surface treatment and the orthodontic resin. 


\section{REFERENCES}

1. Pithon MM, Santos RL, Oliveira MV, Ruellas ACO. Estudo comparativo in vitro da resistência ao cisalhamento da colagem e do índice de remanescente adesivo entre os compósitos Concise e Fill Magic. Rev Dental Press Ortod Ortop Facial. 2006:11(4):76-80.

2. Powers JM, Kim HB, Turner DS. Orthodontic adhesives and bond strength testing. Semin Orthod. 1997 Sep;3(3):147-56.

3. Schmage P, Nergiz I, Herrmann W, Ozcan M. Influence of various surface-conditioning methods on the bond strength of metal brackets to ceramic surfaces. Am J Orthod Dentofacial Orthop. 2003;123(5):540-6.

4. Sinha PK, Nanda RS, Duncanson MG, Hosier MJ. Bond strengths and remnant adhesive resin on debonding for orthodontic bonding technique. Am J Orthod Dentofacial Orthop. 1995:108(3):302-7.

5. Trimpeneers LM, Verbeeck RM, Dermaut LR, Moors MG. Comparative shear bond strength of some orthodontic bonding resins to enamel. Eur J Orthod. 1996:18(1):89-95

6. Wang WN, Li CH, Chou TH, Wang DD, Lin LH, Lin CT. Bond strength of various bracket base designs. Am J Orthod Dentofacial Orthop. 2004;125(1):65-70

7. Reynolds IR, von Fraunhofer JA. Direct bonding of orthodontic attachments to teeth: the relation of adhesive bond strength to gauze mesh size. Br J Orthod. 1976:3(2):91-5

8. Zachrisson BU. Bonding in orthodontics. In: Swain TGB, editor. Orthodontics: current principles and techniques. St. Louis: CV Mosby; 1985. p. 485-564

9. Bradburn G, Pender N. An in vitro study of the bond strength of two lightcured composites used in the direct bonding of orthodontic brackets to molars. Am J Orthod Dentofacial Orthop. 1992;102(5):418-26.
10. Bishara SE, Olsen ME, Damon P, Jakobsen JR. Evaluation of a new lightcured orthodontic bonding adhesive. Am J Orthod Dentofacial Orthop. 1998:114(1):80-7

11. Newman GV. Bonding to porcelain. J Clin Orthod. 1993:17:53-5.

12. Zachrisson BU, Buyukyilmaz T. Recent advances in bonding to gold, amalgam, and porcelains. J Clin Orthod. 1993:27(12):661-75

13. Sperber RL, Watson PA, Rossouw PE, Sectakof PA. Adhesion of bonded orthodontic attachments to dental amalgam: in vitro study. Am J Orthod Dentofacial Orthop. 1999:116(5):506-13.

14. Pascotto R. Materiais de colagem e cimentação em ortodontia parte II: sistemas adesivos resinosos. Rev Dental Press Ortod Ortop Facial. 2002:7(3):121-8

15. Bourke BM, Rock WP. Factors affecting the shear bond strength of orthodontic brackets to porcelain. Br J Orthod. 1999:26(4):285-90

16. Chen HL, Lai YL, Chou IC, Hu CJ, Lee SY. Shear bond strength of provisional restoration materials repaired with light-cured resins. Oper Dent. 2008:33(5):508-15.

17. Papacchini F, Magni E, Radovic I, Mazzitelli C, Monticellia F, Goracci C, et al. Effect of intermediate agents and pre-heating of repairing resin on composite-repair bonds. Oper Dent. 2007:32(4):363-71.

18. Costa TR, Ferreira SQ, Klein-Júnior CA, Loguercio AD, Reis A. Durability of surface treatments and intermediate agents used for repair of a polished composite. Oper Dent. 2010;35(2):231-7. 